\title{
Changes of C-Reactive Protein and Erythrocyte Sedimentation Rate Level from Infection and Non-Infection after the Artificial Joint Surgery
}

Min-Ju Kim, Hye-Jeong Kim

Department of Biomedical Laboratory Science, Kyungwoon University, Gumi 39160, Korea

\section{인공관절 수술 후 감염과 비 감염에 따른 C-반응성단백과 적혈구침강속도의 변화 추이}

김민주, 김혜정

경운대학교 임상병리학과

\begin{abstract}
This study aimed to analyze the changes of C-reactive protein (CRP) and erythrocyte sedimentation rate (ESR) measured in acute infection within four weeks post artificial joint surgery to predict potential infection in early stages, provide rapid treatment, and prevent the abuse of antibiotics. This study included 50 patients with acute infection and 50 patients without any symptoms of infection, among patients who received artificial joint replacement surgery on the lower limbs in a four-week period. CRP was the highest two-to-three days after surgery. with $5.77 \pm 3.69$ and $5.17 \pm 3.48$, respectively, in those with infection and without infection. Thereafter, the value rapidly reduced in those without infection. However, it increased again to $3.16 \pm 2.87$ in the group with infection according to the bimodal curve $(p<0.001)$. ESR was the highest two-to-three days after surgery, with $58.8 \pm 24.63$ and $44.08 \pm 21.48$, respectively. Thereafter, the value slowly reduced in those without infection. However, it was increased again to $47.62 \pm 26.26$ in those with infection according to the bimodal curve $p<0.001)$. As this study shows, if there is an increasing trend for CRP and ESR after artificial joint replacement surgery, it may be possible to question whether patients are acutely infected post surgery. In particular, this result is expected and regarded as a useful factor for diagnosing infection due to the high level of sensitivity and uniqueness for CRP.
\end{abstract}

Key words: Arthroplasty, C-reactive protein, Erythrocyte sedimentation rate, Infection, Inflammation

This is an Open Access article distributed under the terms of the Creative Commons Attribution Non-Commercial License (http://creativecommons.org/licenses/by-nc/4.0) which permits unrestricted non-commercial use, distribution, and reproduction in any medium, provided the original work is properly cited.

Copyright (c) 2016 The Korean Society for Clinical Laboratory Science. All rights reserved.
Corresponding author: Hye-Jeong Kim Department of Biomedical Laboratory Science, Kyungwoon University, 730 Gangdong-ro, Sandong-myeon, Gumi 39160, Korea Tel: 82-54-479-1283 Fax: 82-54-479-1280 E-mail: hjkim11@ikw.ac.kr

Received: October 19, 2016

Revised $1^{\text {st: }}$ November 16, 2016 Revised $2^{\text {nd }}$ : November 21, 2016 Revised $3^{\text {rd: }}$ : November 22, 2016

Accepted: November 22, 2016

\section{서 론}

고령화사회가 되면서 우리나라도 점차 퇴행성관절염 환자가 증 가하는 추세이다. 이러한 관절염의 치료는 환자에 따라 비수술적 요법인 보존적 치료와수술적 치료를 고려해 볼수 있으며, 그 중수 술적 치료로 인공관절 치환술이 있다. 인공관절 치환술이란 관절과
골두를 모두 절제하고 인공재료로 만든 관절로 치환하는 수술이다. 인공관절 치환술은 1960년경 John Charnley에 의해 영국에서부 터 시행되어 지속적으로 발전해 왔으며 통증을 경감하고 관절운동 을 증대시키며 일상적 활동이 가능하게 만들 수 있는 안전하고 효 과적 수술 중 하나이다. 대상이 되는 질환은 변형성 관절증, 만성관 절 류마티즘, 관절근방의 골종양, 그밖에 관절기능의 고도의 황폐 
를 가져오는 질환이며, 고관절에서 가장 빨리 개발되어 가장 많이 사용되고 있으며 슬관절이 그 뒤를 잇는다. 그밖에 어깨, 팔꿈치, 손 가락, 족관절 등에서도 사용된다. 인공관절 치환술은 정형외과 영 역에서 가장 성공적인 수술방법의 하나이며, 대부분의 예에서 그 결과가 좋고, 장기적으로도 환자의 만족도가 높다. 그러나, 기계적 해리와 심부감염은 아직 완전히 해결되지 않은 인공관절 치환술의 합병증들로서 일단 발생 할 경우 매우 나쁜 예후를 보일 수 있으므 로 그 예방에 최선을 다해야 한다[1,2]. 특히 수술 후 4 주 이내의 급 성 술 후감염(acute postoperative infection)이 발생하였을 때 전 형적인 배농이나 수술부위의 심한 통증 혹은 열감 등의 뚜렷한 임 상적 경과를 보이는 경우가 흔하지는 않으며, 이를 정확히 진단하 고 적극적인 치료를 시행하기 위한 결정을 내리기는 십지 않다 [3,4]. 확진된 삽입물 주위 심부 감염의 경우, 삽입물을 제거하고 2 단계 재치환술을 시행하는 방법이 일반적으로 추천되나[5,6], 술 후 4 주 이내의 급성기 감염 일 경우에는 인공관절 주위 세척술 만으 로도 좋은 결과를 얻을 수 있다고 보고되고 있다[7,8]. 그러나 수술 후 심부 감염의 조기 진단은 매우 어려워, 일반 방사선 사진의 경우 적어도 2에서 4주 후에 특징적인 소견이 보이며 동위원소, 자기공 명영상 등은 수술 자체로 인한 효과로 판독에 어려움이 있어 일차 적 방법으로 사용되기 어렵다. 그러므로 감염을 조기에 예측하기 위하여 발열과 같은 감염 징후 포착 외에 혈액학적 검사로 백혈구 (white blood cell, WBC count), 적혈구침강속도(erythrocyte sedimentation rates, ESR), C-반응성단백(C-reactive protein, $\mathrm{CRP}$ ) 등의 혈액학적 표지자가 주로 사용되고 있다[9,10]. 이는 급 성 화농성 감염의 진단뿐만 아니라 경과 추적, 치료 효과 및 예후를 판정하는 지표로도 광범위하게 이용되어 왔으며 인공 관절 치환술 후 대부분의 경우에 적혈구 침강속도 및 C-반응성 단백질 검사가 술 후감염의 진단과 염증에서 회복되는 척도로 사용되고 있다[11]. 이에 본 연구에서는 인공 관절 치환술 후 감염의 조기 진단에 도 움이 되고자, 인공관절 술 후 4주 이내 발생하였던 급성 감염 환자 들과 비 감염 환자들을 대상으로 술 후 기간별 C-반응성 단백질 검 사와 적혈구 침강속도를 연속적으로 측정하여 비교하고 그 변화양 상에 대하여 분석하고자 한다.

\section{대상 및 방법}

\section{1. 연구대상}

하지 인공관절 전치환술 및 재치환술을 시행 받은 환자 중 4 주 이 내에 급성 술 후 감염(acute postoperative infection)이 발생한 환 자 50예(인공 고관절 치환술: 36예, 인공 슬관절 치환술: 14 예)를 대상으로 하였다. 환자의 평균 나이는 73.04세(범위: 52 85세)였
으며, 감염 환자군 과의 비교를 위하여 같은 기간 동안 수술을 시행 하였던 환자 중 어떠한 감염 징후도 없었던 비감염군 50 예(인공 고 관절 치환술: 25 예, 인공 슬관절 치환술: 25 예)를 무작위로 선택하 여 CRP와 ESR 수치를 조사하였으며, 이들의 평균 나이는 73.12세 (범위:63 84세)였다(Table 1).

술 후 4주 이후에 발생한 만성 지연 감염(late chronic infection) 환자들은 대상에서 제외하였으며, 술 후 CRP와 ESR에 영향을 미칠 수 있는 오류 가능성을 배제하기 위하여 감염 군과 비감염군 모두 에서 내과적 혹은 전신적 합병증으로 폐렴, 요로감염, 색전증 등을 동반한 환자들은 연구 대상에서 제외하였다. 본 연구는 경운대학교 생명윤리심의위원회(IRB)의 승인을 받았다(KWU-2016-01).

\section{2. 연구방법}

\section{1) 생화학적 분석}

혈청의 C-반응성단백질(CRP) 함량 검사는 Cobas c501 (Roche, Rotkreuz, Switzerland) 기기에서 CRPL3 (Roche, Mannheim, Germany) 시약을 사용하여 Turbidimetric Immunoassay (TIA) 법으로 측정하였고, $0.5 \mathrm{mg} / \mathrm{dL}$ 이하를 정상범위로 하였다.

\section{2) 혈액학적 분석}

적혈구침강속도(ESR)는 K2EDTA가 첨가된 용기에 혈액을 담고 mix 후 VES MATIC (Diagnostica Senese, Monteriggioni, Italy) 기기에서 ves tec cuvette를 사용하여 Westergren 법으로 측정하 였고, 연령과 성별에 관계없이 $20 \mathrm{~mm} / \mathrm{hr}$ 이하를 정상 범위로 정하 였다.

\section{3) 기간별 $\mathrm{CRP}$ 와 $\mathrm{ESR}$ 의 측정 및 분석}

감염이 있었던 환자군 50예(고관절 36예, 슬관절 14 예)의 CRP 와 ESR의 수치를 술 전, 술 후 1 기(수술 후 $24 \mathrm{hr}$ 이내), 2 기(수술 후

Table 1. Demographic characteristics of patients in infection and non-infection groups

\begin{tabular}{lcc}
\hline $\begin{array}{c}\text { Demographics } \\
\text { (No. of patients) }\end{array}$ & Infection & Non-infection \\
\hline Types of operation & THA: 36 & THA: 25 \\
& TKA: 14 & TKA: 25 \\
Age & $51 \sim 60: 1$ & $51 \sim 60: 0$ \\
& $61 \sim 70: 13$ & $61 \sim 70: 11$ \\
& $71 \sim 85: 36$ & $71 \sim 85: 39$ \\
Sex & Male: 5 & Male: 10 \\
& Female: 45 & Female: 40 \\
Total & 50 & 50 \\
\hline
\end{tabular}

Abbreviation: THA, Total hip arthroplasty; TKA, Total knee arthroplasty. 
Table 2. The division of the time period after the operation

\begin{tabular}{cccccccc}
\hline & Pre OP. & 1st $p$. & 2nd $p$. & 3rd $p$. & 4th $p$. & 5th $p$. & 6th $p$. \\
\hline \multirow{2}{*}{ POD } & Pre OP & Post OP & Post OP & Post OP & Post OP & Post OP & Post OP \\
& & 1 day & $2 \sim 3$ day & $4 \sim 7$ day & $8 \sim 14$ day & 15 21 day & 22 30 day \\
\hline
\end{tabular}

Abbreviation: Pre OP, preoperative; $p$, period; Post OP, postoperative.

Table 3. The comparison of CRP level among infection and non-infection

\begin{tabular}{lccccccc}
\hline \multicolumn{1}{c}{ Groups } & Pre OP. & 1st p. & 2nd p. & 3rd p. & 4th p. & 5th p. & 6th p. \\
\hline Infection & $0.22 \pm 0.32$ & $1.69 \pm 2.45$ & $5.77 \pm 3.69$ & $3.01 \pm 2.74$ & $1.62 \pm 3.80$ & $3.16 \pm 2.87$ & $1.16 \pm 2.31$ \\
Non-infection & $0.34 \pm 0.43$ & $1.84 \pm 2.57$ & $5.17 \pm 3.48$ & $3.53 \pm 2.70$ & $1.07 \pm 1.26$ & $0.72 \pm 1.31$ & $0.29 \pm 0.40$ \\
$p$-value & 0.13 & 0.76 & 0.40 & 0.34 & 0.33 & $<0.001^{* * *}$ & $0.0161^{*}$ \\
\hline
\end{tabular}

The value with an asterisk is significantly different from infection group and non-infection by t-test $\left({ }^{\star} p<0.05,{ }^{* \star *} p<0.001\right)$. Abbreviation: CRP, C-reactive protein.

2 3일), 3기(4 7일), 4기(8 14일), 5기(15 21일), 6기(22 30 일)로 나누어 측정하고(Table 2), 같은 기간 감염이 없었던 환자 군 50예(고관절 25예, 슬관절 25예)의 $\mathrm{CRP}$ 와 $\mathrm{ESR}$ 의 변화 양상을 측정하여 비교하고 변화 양상에 대해 분석하였다.

\section{4) 통계적 방법}

감염군과 비감염군 간의 기간별 $\mathrm{CRP}$ 및 $\mathrm{ESR}$ 측정값 비교분석은 t-test를 이용하였다. 유의성의 판정은 $p$ 값이 0.05 미만으로 하였 으며, 모든 통계 처리는 SPSS version 13.0 (SPSS Inc., Chicago, IL, USA)을 사용하였다.

\section{결 과}

\section{1. 수술 후 CRP 변화 양상}

감염 환자 군과 감염이 없는 환자군의 술 전 평균 $\mathrm{CRP}$ 수치는 $0.23 \pm 0.32 / 0.35 \pm 0.44$ 이었다. 술 후 $\mathrm{CRP}$ 의 평균 수치가 1 기(수 술직후)는 $1.67 \pm 2.41 / 1.85 \pm 2.57,2$ 기( $2 \sim 3$ 일)는 $5.78 \pm 3.69 /$ $5.18 \pm 3.48,3$ 기(4 7일)는 $3.01 \pm 2.74 / 3.53 \pm 2.71$, 술 후 4 기 (8 14일)는 $1.62 \pm 3.80 / 1.07 \pm 1.26$ 이었고, 술 전과 4 기 까지 $\mathrm{CRP}$ 는 두 군 간에 통계적으로 유의한 차이는 발견할 수 없었다. 그 러나 술 후 5기(15 21일)는 $3.17 \pm 2.88 / 0.72 \pm 1.32$ ( $p<0.001$ ), 술 후 6기(22 30일)는 $1.16 \pm 2.32 / 0.29 \pm 0.40(p<0.05)$ 으로 감 염군에서 통계학적으로 유의하게 높게 나타났다(Table 3).

비감염군에서는 술 후 1 3일(2기)째 CRP의 급격한 상승 후 수 술 3 주째까지 지속적인 감소 추세를 나타내지만, 감염 군에서는 술 후 약 2 3주경(5기)에 CRP의 재상승이 나타나는 bimodal curve 를 보였다(Fig. 1).

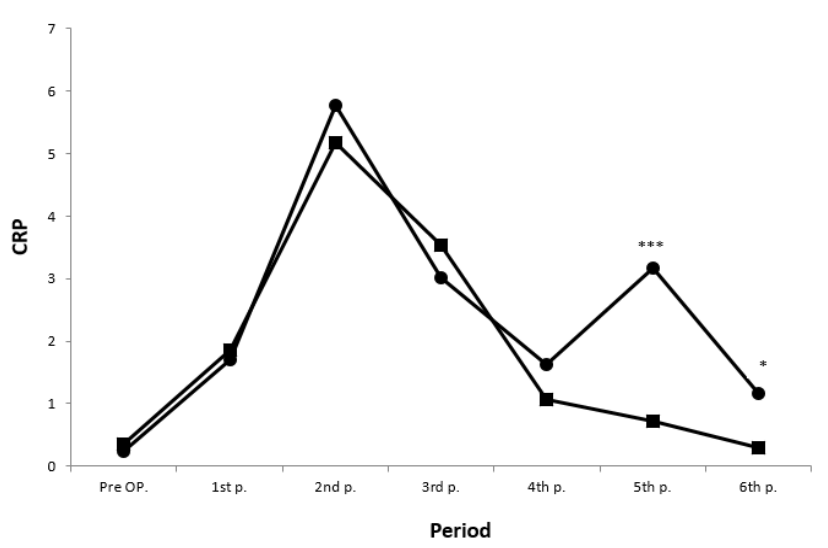

Fig. 1. Changing pattern of CRP in infection and non-infection groups. Infection groups showed bimodal increase in the CRP level around the 2 nd or 5 th period. The value with an asterisk is significantly different from infection group and non-infection by t-test $\left({ }^{\star} p<0.05,{ }^{\star \star \star} p<0.001\right)$. Abbreviation: CRP, C-reactive protein; Infection group, --; No infection group, -

\section{2. 수술 후 ESR 변화 양상}

감염 환자 군과 감염이 없는 환자군의 술 전 평균 $\mathrm{ESR}$ 수치는 $28.56 \pm 20.91 / 25.1 \pm 14.11$ 이었다. 술 후 $\mathrm{ESR}$ 의 평균 수치가 1기 (수술직후)는 $19.5 \pm 15.89 / 19.36 \pm 11.72$ 이었고, 술 전과 1 기 $\mathrm{ESR}$ 은 두 군간에 통계적으로 유의한 차이는 없었으나 술 후 $\mathrm{ESR}$ 의 평균 수치가 2기(2 3일)는 58.8 $\pm 24.63 / 44.08 \pm 21.48$ ( $p<0.01)$, 술 후 3기(4 7일)는 59.18 $\pm 30.21 / 46.68 \pm 23.29$ ( $p<0.05)$, 술 후 5기(15 21일)에서 47.62 $\pm 26.27 / 28.98 \pm 18.58(p<0.001)$, 술 후 6기(22 30일)에서 37.52 $\pm 24.82 / 19.8 \pm 14.89$ ( $p<0.001)$ 는 통계학적으로 유의한 차이를 보였다(Table 4).

비감염군에서는 술후 2 3일(2기)째 ESR의 급격한 상승 후3기부 터서서히 감소하는 추세를 나타내지만, 감염 군에서는 술후약 2 3 주경(5기)에 ESR이 다시 상승하는 bimodal curve를 보였다(Fig. 2). 
Table 4. The comparison of mean ESR level among infection and non-infection

\begin{tabular}{lccccccc}
\hline \multicolumn{1}{c}{ Groups } & Pre OP. & 1st p. & 2nd p. & 3rd p. & 4th p. & 5th p. & 6th p. \\
\hline Infection & $28.56 \pm 20.91$ & $19.5 \pm 15.89$ & $58.8 \pm 24.63$ & $59.18 \pm 30.20$ & $42.18 \pm 28.54$ & $47.62 \pm 26.26$ & $37.52 \pm 24.82$ \\
Non-infection & $25.1 \pm 14.11$ & $19.36 \pm 11.71$ & $44.08 \pm 21.48$ & $46.68 \pm 23.29$ & $37.76 \pm 20.17$ & $28.98 \pm 18.58$ & $19.8 \pm 14.88$ \\
$p$-value & 0.34 & 0.96 & $0.002^{* *}$ & $0.02^{*}$ & 0.37 & $<0.001^{* * *}$ & $<0.001^{* * *}$ \\
\hline
\end{tabular}

The value with an asterisk is significantly different from infection group and non-infection by t-test $\left({ }^{\star} p<0.05,{ }^{\star *} p<0.01,{ }^{\star \star \star} p<0.001\right)$. Abbreviation: ESR, Erythrocyte sedimentation rate.

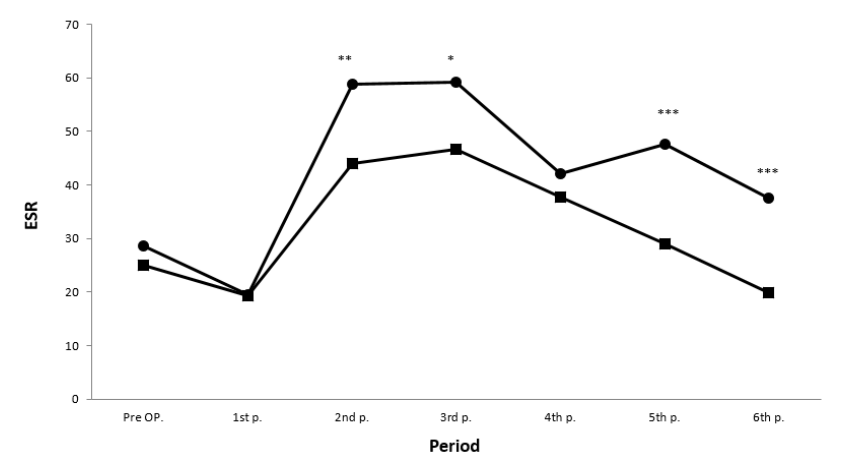

Fig. 2. Changing pattern of ESR in infection and non-infection groups. Infection groups showed bimodal increase in the ESR level around the 2 nd and $3 r d$ or 5th period. The value with an asterisk is significantly different from infection group and non-infection by t-test $\left({ }^{\star} p<0.05,{ }^{\star \star} p<0.01,{ }^{\star \star \star} p<0.001\right)$. Abbreviation: ESR, erythrocyte sedimentation rate; Infection group, - -; No infection group,

\section{3. 민감도, 특이도, 양성 및 음성 예측도}

감염 군에서 $\mathrm{CRP}$ 의 bimodal curve 양상을 보이는 경우는 총 50 예 중 46예(92\%)였으며, 비감염군에서 bimodal curve 양상인 경 우는 총 50 예 중 3 예(6\%)였다. 즉 CRP의 bimodal curve 양상을 보 일 경우 감염에 대한 민감도 $92.0 \%$, 특이도 $94.0 \%$, 양성률 $93.9 \%$, 음성률 $92.1 \%$ 로 나타났다.

또한 감염 군에서 $\mathrm{ESR}$ 의 bimodal curve 양상을 보이는 경우는 총 50예 중 50예(100\%)였으며, 비감염군에서 bimodal curve 양 상인 경우는 총 50예 중 7예(14\%)였다. 즉 ESR의 bimodal curve 양상을 보일 경우 감염에 대한 민감도 $100 \%$, 특이도 $86.0 \%$, 양성률 $87.7 \%$, 음성률 $100 \%$ 로 각각 나타났다(Table 5).

\section{고 찰}

인공관절 치환술 후 감염의 발생 시 조기 진단은 감염 치료의 결 과에 중요한 영향을 미칠 수 있으며, 환자의 예후에 심각한 영향을 미칠 수 있다. 그러나, 인공관절 치환술 후 감염은 진단 자체가 어려 운 경우가 많으며, 진단이 되었더라도 치료지침을 결정하기가 수월 하지 않아 치료가 어려운 합병증이다. 이에 감염에 대한 효과적인 진단방법과 치료방침에 대해서는 여러 다양한 방법들이 소개되고
Table 5. Diagnostic performances (sensitivity, specificity, positive predictive value and negative predictive value) with bimodal curve in infection and non-infection groups

\begin{tabular}{lcc}
\hline & CRP & ESR \\
\hline Sensitivity (\%) & $92.0(46 / 50)$ & $100(50 / 50)$ \\
Specificity (\%) & $94.0(47 / 50)$ & $86.0(43 / 50)$ \\
PPV (\%) & $93.8(46 / 49)$ & $87.7(50 / 57)$ \\
NPV (\%) & $92.1(47 / 51)$ & $100(43 / 43)$ \\
\hline
\end{tabular}

Abbreviation: PPV, positive predictive value; NPV, negative predictive value.

있다[9-13]. 인공관절 치환술 후 감염은 창상 치유 지연, 수술 창상 누공 및 배농, 지속적인 술 후 통증과 같은 임상적인 병력과 진찰 소 견으로 진단을 내릴 수 있으며[11], 염증 진단에 이용될 수 있는 방 법에는 C-반응성단백질, 적혈구침강 속도, 백혈구, interleukin-6, tumor necrosis factor- $\alpha$ [12]와 같은 혈액학적 검사나 골 주사 검 사나 양전자 방출 단층촬영(positron emission tomography)과 같은 동위 원소 검사를 이용할 수 있으나, 현재 임상에서 적혈구 침 강속도와 C-반응성단백질을 많이 사용하고 있다. 이에 본 연구에 서도 비교적 검사가 간편하고 비용이 적게 드는 C-반응성단백질과 적혈구 침강속도를 이용하여 4주 이내의 조기 감염을 예측하고자 하였다.

초기 급성기 염증반응 단백 중에서 대표적인 것으로 C-반응성 단백질이 있으며 $[14,15]$, C-반응성 단백질은 급성기 반응 단백질 중에서 가장 객관적 이며 감수성(sensitivity)이 높은 것으로 평가 되고 있고, 염증으로부터 회복되어 정상화 되는 기간이 적혈구 침 강 속도 보다 빠른 것으로 알려져 있다[16]. 일반적으로 감염이 없 는 인공관절 수술 후 $\mathrm{CRP}$ 수치 변화에 대한 연구에서 대부분 술 후 2 3일째 최고치를 보이다가 점차 감소하여 술 후 2 3주째에는 수술 전과 비슷한 정도로 돌아온다고 보고되고 있다[13,17]. 본 연 구에서는 술 후 3 주 이후 정상치로 회복되는 양상을 보였는데 이는 연구대상의 평균 연령이 73 세의 고령으로서 술 후 정상 회복 속도 가 느린 것으로 사료된다.

적혈구 침강속도는 급성 감염이 있는 경우에 치료에 반응하여 정상 수치로 서서히 감소하는 특성을 가지고 있어 술 후 감염의 진 단 방법으로 사용되었다. 그 외에 결핵성 감염, 류마티스성 관절염 
등 만성 감염 질환의 선별 검사와 질병의 경과 추적 및 질병의 활동 성을 나타내는 지표로 이용되었다[11]. 감염 이외에도 고령의 노인 [18], 임산부[3], 빈혈, 헤파린(heparin)이나 피임약[18] 등을 복용 한 사람에게서 높을 수 있고, 수술을 받거나 부상을 당한 경우에 있 어서도 증가할 수 있다[20]. 이처럼 적혈구 침강속도에 영향을 주는 요소가 다양하고 정상 범위가 넓기 때문에 특이성이 없으며, 따라 서 해석할 때 이러한 특성이 고려되어야 하겠다.

Suh 등[11]은 33명의 인공관절 치환술 심부감염환자에서 C-반 응성단백질의 수치가 술 후 2 3일에 최고치에 도달한 후 감소하다 가 술 후 13일경 재 상승하는 bimodal curve 양상을 보고하고 있 다. 본 연구에서도 술 후 $2 \sim 3$ 일에 C-반응성단백질 및 적혈구침강 속도가 가장 높았으며, C-반응성단백질은 급격히 하강하여 수술 후 4 7일경에는 비감염군이 감염군에 비해 다소 높은 수치를 보였 으나 이는 비감염상태의 의미없는 양상으로 보여지며, 술 후 2주에 서 정상치를 나타내었다. 그러나 감염 발생 시 CRP는 술 후 $15 ~ 21$ 일경(5기)에 재상승이 나타나는 bimodal curve를 나타내었다. 적 혈구침강속도는 서서히 감소하여 술 후 21일경에 정상범위로 회복 되었으나 감염 발생 시 ESR도 15 21일경(5기)에 재상승이 나타 나는 bimodal curve를 나타내었다.

감염군에서 C-반응성단백질의 bimodal curve 민감도(sensitivity) 는 $92.0 \%$, 특이도(specificity) 94.0\%, 양성예측도(positive predictive value) $93.8 \%$, 음성 예측도(negative predictive value) 92.1\%를 보였고, 적혈구 침강속도의 bimodal curve 민감도 (sensitivity)는 100\%, 특이도(specificity) $86.0 \%$, 양성예측도 (positive predictive value) $87.7 \%$, 음성 예측도(negative predictive value) $100 \%$ 로 높은 음성 예측도를 보이고 있다. 적혈구 침강속도 는 실제 감염이 있는 환자 중에서 감염을 가려내는 확률보다 감염 이 없는 환자 중에서 감염이 없는 경우를 가려내는 확률이 높다고 설명할 수 있으며 따라서 감염을 진단하기 위한 방법 보다는 감염 을 배제하기 위한 수단으로 더 유용할 것으로 사료된다.

Horan 등[20]의 보고에 따르면 CRP의 수술 후 감염의 예측인자 로서의 의미는 수술 후 7일 이상경과 후에도 정상 수치로의 회복을 보이지 않고 증가된 소견을 보이거나 재상승을 보이는 경우 감염을 의심할 수 있다고 보고하고 있다. 본 연구도 같은 양상을 보이고 있 으나 CRP 수치에 대한 개인차가 있을 수 있고, 술 후 급성기에 수술 부위 이외의 다른 염증성 반응을 정확히 배제하기가 어려운 제한점 은 있다고 하겠다.

본 연구는 4 주 이내의 급성 술 후 감염에서 C-반응성단백질과 적혈구침강속도의 변화 양상을 관찰하여, 술 후 5 기(15 21일)경 재 증가하는 양상을 보일 경우 감염의 가능성이 높다는 결론을 얻 었다. 또한, CRP와 ESR 모두 인공관절 치환술 후 감염 등 초기 합병
증에 대한 감시 지표로서 유용한 것으로 보이며, 특히 CRP는 보다 감수성이 높은 방법으로 판단된다.

\section{요 약}

인공 관절 치환술 후 감염의 조기 진단에 도움이 되고자, 인공관 절 술 후 4주 이내 발생하였던 급성 감염 환자들과 비 감염 환자들을 대상으로 술 후 기간별 $\mathrm{C}$-반응성 단백질 검사와 적혈구 침강속도 를 연속적으로 측정하여 비교하고 그 변화 양상에 대하여 분석하고 자 하였다. 하지 인공관절 치환술을 시행 받은 환자 중 4 주 이내에 급성 감염이 발생한 환자 50예와어떠한 감염 징후도 없었던 환자 50 예를 대상으로 하였다. C-반응성단백 및 적혈구침강속도의 측 정은 수술 전, 수술 직후, 수술 후 2 3일, 수술 후 4 7일, 수술 후 8 14일, 수술 후 15 21일, 수술 후 22 31일 사이에 시행하였 다. 연구결과 C-반응성단백은 감염과 비 감염 군에서 술 후 2 3일 에각각 $5.77 \pm 3.69$ 및 $5.17 \pm 3.48$ 로 가장 높았고, 이후 비감염 군 에서는 급격히 감소하여 술 후 $15 \sim 21$ 일에 $0.72 \pm 1.31$ 로 정상 범 위를 보였지만, 감염 군에서는 $3.16 \pm 2.87$ 로 재상승하는 bimodal curve를 보였으며, 두 군간의 유의한차이를 나타내었다 $(p<0.001)$. 적혈구침강속도는 감염과 비 감염 군에서 술 후 2 3일에 각각 $58.8 \pm 24.63$ 및 $44.08 \pm 21.48$ 로 급격히 증가하고 $(p<0.01)$. 이 후 비감염 군에서는 서서히 감소하여 술 후 $15 \sim 21$ 일에 $28.98 \pm 18.58$ 로 정상 범위를 보였지만, 감염 군에서는 $47.62 \pm 26.26$ 으로 재상 승하는 bimodal curve를 보였으며, 두 군 간의 유의한 차이를 나타 내었다 $(p<0.001)$. 본 연구결과 인공관절 치환술 후 C-반응성단백 및 적혈구침강속도가 재상승하는 양상을 보일 경우 급성 술 후 감 염을 의심할 수 있으며, 특히 C-반응성단백은 높은 민감도와 특이 도를 나타내므로 감염을 진단하는 인자로 유용하다 할 수 있다. 이 를 통해 감염 의심 환자를 조기에 예측하여 신속한 처치와 항생제 남용을 방지함으로써 전신적인 합병증으로 확대되는 것을 최소화 할 수 있을 것으로 사료된다.

\section{Acknowledgements: None \\ Funding: None \\ Conflict of interest: None}

\section{References}

1. Galat DD, McGovern SC, Larson DR, Harrington JR, Hanssen $\mathrm{AD}$, Clarke HD. Surgical treatment of early wound complications following primary total knee arthroplasty. J Bone Joint Surg Am. 2009;91:48-54. 
2. Saleh K, Olson M, Resig S, Bershadsky B, Kuskowskid M, Gioe T, et al. Predictors of wound infection in hip and knee joint replacement: results from a 20 year surveillance program. J Orthop Res. 2002;20:506-515.

3. Ugras AA, Kural C, Kural A, Demirez F, Koldas M, Cetinus E. Which is more important after total knee arthroplasty: local inflammatory response or systemic inflammatory response? Knee. 2011;18:113-116.

4. Bilgen O, Atici T, Durak K, Karaeminoğullari, Bilgen MS. C-reactive protein values and erythrocyte sedimentation rates after total hip and total knee arthroplasty. J Int Med Res. 2001; 29:7-12.

5. Koo KH, Yang JW, Cho SH, Song HR, Park HB, Ha YC, et al. Impregnation of vancomycin, gentamicin, and cefotaxime in a cement spacer for two stage cementless reconstruction in infected total hip arthroplasty. J Arthroplasty. 2001;16:882-892.

6. Estes CS, Beauchamp CP, Clarke HD, Spangehl MJ. A two stage retention debridement protocol for acute periprosthetic joint infections. Clin Orthop Relat Res. 2010;468:2029-2038.

7. Van Kleunen JP, Knox D, Garino JP, Lee GC. Irrigation and debridement and prosthesis retention for treating acute periprosthetic infections. Clin Orthop Relat Res. 2010;468:20242028.

8. Chiu FY, Chen CM. Surgical debridement and parenteral antibiotics in infected revision total knee arthroplasty. Clin Orthop Relat Res. 2007;461:130-135.

9. Shen H, Zhang N, Zhang X, Ji W. C-reactive protein levels after 4 types of arthroplasty. Acta Orthop. 2009;80:330-333.

10. Dupont C, Rodenbach J, Flachaire E. The value of C-reactive protein for postoperative monitoring of lower limb arthroplasty. Ann Readapt Med Phys. 2008;51:348-357.

11. Suh YS, Choi HS, Nho JH, Won SH, Choi JW, Lee JC, et al. Prediction of early postoperative infection after arthroplasty using the C-reactive protein level. J Korean Orthop Assoc.
2012;47;133-139.

12. Kim YH, Park H. Study on the anti-Inflammatory activity and mechanism of medicinal plants used in the treatment of arthritis. Korean J Clin Lab Sci. 2016;48:176-182.

13. Berbari E, Mabry T, Tsaras G, Spangehl M, Erwin PJ, Murad MH, et al. Inflammatory blood laboratory levels as markers of prosthetic joint infection: a systematic review and meta-analysis. J Bone Joint Surg Am. 2010;92:2102-2109.

14. Piper KE, Jacobson MJ, Cofield RH, Sperling TW, SanchezSotelo J, Osmon DR, et al. Microbiologic diagnosis of prosthetic shoulder infection by use of implant sonication. J Clin Microbiol. 2009; 47:1878-1884.

15. Park SK. Gender difference in the association of metabolic syndrome with hs-CRP concentration of blood. Korean J Clin Lab Sci. 2012; 44:86-96.

16. Fischer CL, Gill CW, Forrester MG, Nakamura R. Quantitation of acute phase proteins postoperatively. Value in detection and monitoring of complications. Am J Clin Pathol, 1976;66:840846.

17. Park KK, Kim TK, Chang CB, Yoon SW, Park KU. Normative temporal values of CRP and ESR in unilateral and staged bilateral TKA. Clin Orthop Relat Res. 2008;466:179-188.

18. Vilchez F, Martinez-Pastor JC, Garcia-Ramiro S, Bori1 G, Macule F, Sierra J, et al. Outcome and predictors of treatment failure in early post-surgical prosthetic joint infections due to Staphylococcus aureus treated with debridement. Clin Microbiol Infect. 2011;17:439-444.

19. Tsukayama DT, Estrada R, Gustilo RB. Infection after total hip arthroplasty. A study of the treatment of one hundred and six infections. J Bone Joint Surg Am. 1996;78:512-523.

20. Horan TC, Gaynes RP, Martone WJ, Jarvis WR, Emori TG. CDC definitions of nosocomial surgical site infections, 1992: a modification of CDC definitions of surgical wound infections. Am J Infect Control. 1992;20:271-274. 